\title{
The Underperformance of Young Closed-End Funds in Greece
}

\author{
Dimitrios V. Kousenidis* \\ Aristotle University of Thessaloniki, Greece \\ Christos I. Negakis \\ University of Macedonia, Greece
}

In the present paper we study the performance of young closed-end funds (CEFs) in Greece. Using monthly CEF data from 1997 to 2007, we provide evidence showing that young funds underperform both old funds and the market. As in Kaplan and Schoar (2005), we note that new underperforming funds occur more frequently during hot market periods, potentially due to the presence of uninformed investors. The entrance of the newly raised funds in the market dilutes the overall industry performance and motivates financial institutions to take over fairly-performing subsidiary funds. As a result, well-performing funds are gradually delisted from the market and eventually only poor-performing funds survive. In this context the take-over activities prevail as a rational explanation for the underperformance and the shrinking of the closed-end fund industry in Greece. (JEL: G12, G20, G23)

Keywords: closed-end funds, young fund underperformance, models of portfolio performance, ATHEX

\section{Introduction}

The evaluation of the performance of managed portfolios in emerging and developed capital markets, such as closed-end funds (CEFs) and mutual funds, has been an interesting issue. The popular belief is that managers of such funds possess superior skills and the knowledge needed to pick shares of successful companies (selectivity skills) and to

* Corresponding Author: Dimitrios Kousenidis, Aristotle University of Thessaloniki, School of Economics, Department of Business Administration, 54124 Thessaloniki, Greece. E-mail addresses: dkous@econ.auth.gr (D.V. Kousenidis); negakis@uom.gr (C.I. Negakis)

(Multinational Finance Journal, 2013, vol. 17, no. 1/2, pp. 107-148)

(C) Multinational Finance Society, a nonprofit corporation. All rights reserved. DOI: $10.17578 / 17-1 / 2-4$ 
exploit market movements (timing skills) for profit making. ${ }^{1}$ Nevertheless, the empirical investigation of the latter belief has produced mixed results.

Typically, managed portfolio performance studies have used regression models to examine the extent to which the performance of portfolios is due to managers' selectivity and timing skills. These models are generally variants of the popular capital asset pricing model (CAPM), where fund returns are broken down into their selectivity and timing components. Moreover, the majority of studies have focused on financial environments with many commonalities, such as those in the US, UK and Australia. Interestingly, the reported findings do not always support the assertion that fund managers exhibit portfolio superiority. For example, Dimson and Minio-Kozerski (1999, 2001), Giles, Wilsdon and Worboys (2002) and Allen, Brailsford, Bird and Faff (2003) offer an extensive review of many studies and conclude that superior managerial performance (if any) is at best transitory. On the contrary, these studies suggest that many funds, especially young funds and funds of small capitalization underperform as compared to several benchmark portfolios. What is more, underperformance is shown to persist over time and increases the probability of future poor performance and loss of funds.

More recently, Kaplan and Schoar (2005) examined the performance of private equity funds and observed that, during upturns in the market, many new funds enter the market. The newly raised funds generally underperform and dilute the overall industry performance. However, established funds are not likely to be affected and, on average, exhibit better performance than young and newly raised funds. Berk and Stanton (2007) and Cherkes, Sagi and Stanton (2009) examine the behavior of the premium/discount of CEFs and in this context confirm the result of the underperformance of young funds. Specifically, their

1. The term selectivity refers to the ability of a portfolio manager to pick successful shares; the term "timing" refers to the ability of the manager to foresee the movements of the market and adjust the risk of the portfolio towards the right direction (see Fama, 1972). The existence of managerial skills does not contradict the EMH. Grossman and Stiglitz (1980) provide a version of EMH, which assumes that information is not free. Therefore, some managers may possess valuable private information that is not shared by the market as a whole. The excess returns of active managers are then presumed to concur with the information-gathering costs incurred. Lang, Litzenberger and Madrigal (1992) also observe that even if noise exists in the market, it does not completely dilute the information content of share prices. In this context they admit that their results describe an environment under which it is not contradictory to assume both traders' rationality and private incentives to acquire information. 
results indicate that young CEFs trade at a premium for an average period of two years after their IPO and then turn to a discount. However, funds that are less than two years old (and consequently trade at a premium) underperform funds that are more than two years old (and consequently trade at a discount) by about forty basis points per month. Given this evidence, Berk and Stanton (2007) wonder why investors appear to be willing to invest in younger funds and admit that the underperformance of young funds remains a puzzling issue that requires further research.

Sentis (2009) expands on Ritter (1991) and examines the long-run underperformance of IPOs. Sentis shows that during periods of intense IPO activity,the presence of uninformed investors allows many underperforming firms to successfully conduct IPOs and enter the market. The underperformance of the new-entrants bears a negative impact on the overall performance of the industry and leaves high-performing firms with two options: either to remain listed and continue investing in a gradually underperforming industry, or be taken over by a friendly bidder and delist their shares from the market. Thus the merging activity which drives well-performing firms out of the market prevails as a rational explanation for the long-run underperformance phenomenon. In the context of fund performance, this explanation complies with Barras, Scaillet and Wermers (2010) who offer as an explanation for long-reported fund-underperformance, the survival over time of a minority of substantially underperforming funds.

In the present paper we offer the first comprehensive study of the underperformance of young CEFs in Greece. Our evidence stems from a unique case that arose in the Greek market within our period of investigation. In this context we provide, for the first time, evidence on the performance of newly raised CEFs both in their pre-IPO and their post-IPO period. Moreover, our relatively long research horizon offers the opportunity to examine the performance of some CEFs "from the cradle to the grave" and hence we are able to relate the underperformance of young funds to the gradual shrinking of the CEF industry in Greece.

In specific, our unique case occurs during the hot market period of 1999, when thirty-one newly incorporated CEFs applied to the Greek Capital Market Commission (GCMC) for approval to list their shares on the Athens Stock Exchange (ATHEX). Two of them were granted approval and went public shortly after their incorporation (as is the 
usual practice). However, because of the subsequent abrupt downturn of the market, the GCMC postponed all scheduled IPOs and hence the remaining twenty-nine new CEFs were left to operate as unlisted funds for a period that spanned from nine to fifty-eight months. During this withholding period, thirteen funds did not make it and they were either taken over by large financial institutions or they were forced to liquidate. In the end, only thirteen out of the twenty-nine funds managed to survive and list their shares on the market. Nevertheless, despite the entrance of new funds in the market, the Greek CEF industry failed to grow. On the contrary, a large number of funds have gradually discontinued operations and, at the end of our research, only eight surviving funds remained.

This particular case offers the opportunity to draw important inferences by examining two distinct but interactive datasets: one set of unlisted CEFs and one set of listed CEFs. In particular, we examine the risk-adjusted performance of various sub-sets of fund data. First, as refers to the unlisted funds we compare the performance of the funds that successfully went public with the performance of the funds which failed to enter the market. We also examine the evolution of the performance of the successful funds in their pre- and post-IPO period. We then turn our analysis to the listed funds sample and compare the performance of a sub-set of young funds with the performance of a sub-set of old funds. Finally, we study whether poor performance is a reason for fund disappearance and examine the performance of the sub-set of funds that survived, as compared to the performance of the funds that have perished from our database.

Our results are free of survivorship bias because our sample includes both young and old funds, as well as surviving and non-surviving funds. We measure fund performance using both NAV and market returns. Our models of performance evaluation are the widely used Jensen (1968) model and the Henriksson and Merton (1981) model, both of which are adjusted to accommodate the Fama and French $(1992,1993)$ mimicking risk factors of size and of the book-to-market ratio. Moreover, in order to avoid any bias arising from the small size of our sample (Pedersen and Satchell, 2000), we also estimate an alternative version of the Asymmetric Response Model (ARM) of Bawa, Brown and Klein (1981) along with its three factor version.

Overall, our findings offer strong support of the young fund underperformance hypothesis. We document that, as concerns the newly incorporated funds, the long period of staying out of the market has 
actually served as a filtering mechanism which has distinguished well-performing from poorly-performing young funds and which has eventually prevented poorly-performing funds from going public. However, even after this filtering process the performance of new funds in the market is disheartening. The newly-listed funds appear unable to outperform old funds, both in terms of NAV and market performance.

Finally, we show that, on-average, non-surviving funds deliver better share returns (although not better NAV returns) than surviving funds, implying that poor performance is not a reason for fund disappearance from the market. On the contrary, we find that many of the high-performing funds that perished have been acquired by large financial institutions, which has resulted in the delisting of their shares from the market. Thus, like Sentis (2009) and Barras, Scaillet and Wermers (2010) we support the prediction that this acquisition activity is the major cause of the survival of only a minority of poorly-performing funds and thus it consists of a rational explanation for the observed underperformance in the closed-end fund industry in Greece.

The results of the paper are interesting for at least two reasons. First, we disclose to the financial authorities of emerging capital markets in Europe and worldwide an explicit case of a closed-end fund industry which has shrunk dramatically over the past few years. Second, given that most previous studies refer to the US or the UK institutional environments, in the present paper we report "out-of-sample" evidence on the performance of managed portfolios of closed-end charters from a small and less developed capital market.

The remainder of the paper is organized as follows. In section II we provide information concerning the legal and institutional framework of closed-end funds in Greece. In section III we describe our data set and construct our return metrics. In section IV we discuss the models used to evaluate portfolio performance. In section $\mathrm{V}$ we present the findings of our empirical analysis. Finally, in section VI we conclude the paper and offer some implications for further research.

\section{Legal and Institutional Framework of CEFs in Greece}

\section{A. Legal Framework}

Closed-end funds in Greece, also known as Portfolio Investment Companies (PICs), are limited liability companies (Société Anonyme), 
which are subject to statutory controls like other corporations. Their primary purpose is to manage a portfolio of transferable securities. The term "transferable securities" refers to shares, debentures, bonds and certificates of deposit. The PICs are governed by Law 3371/2005 (which replaced Law 1969/1991) and must have a minimum share capital of $€ 10,000,000$, which must be paid in total at the time of incorporation. The Greek Capital Market Commission (GCMC) is the only competent authority for providing a license for the incorporation of a PIC.

The PICs must apply for listing in the Athens Stock Exchange (ATHEX) within three months of their incorporation. The funds of PICs can be invested in transferable securities listed on the stock markets of any EU member state or in transferable securities listed on stock markets of non-member states, on the condition that these markets are well regulated, recognized and open to the public. In order to secure diversification, the GCMC requires that, at the time of realizing its placements, a PIC is not allowed to invest more than $10 \%$ of its own funds in securities of the same issuer. In addition, PICs are not allowed to acquire shares of any company representing more than $10 \%$ of the voting share capital of the latter. If the shares acquired exceed the limit of $10 \%$, then the PIC is obliged to sell the excess shares within three months from the date of acquisition.

To secure the transparency of their transactions, PICs are required to publish a table with all their investments every three months, indicating their average acquisition cost and their market value, as well as their total net worth and the per share net asset value (NAV) at current prices. The GCMC is the competent authority for imposing administrative penalties on directors, executives and certain employees of PICs when they infringe upon the provisions of the law. Following a relatively simple procedure, a PIC can be transformed into a mutual (open-end) fund using a special license from the GCMC.

In terms of financing and dividend policy, PICs are allowed to borrow amounts of up to $35 \%$ of their own funds in order to invest in transferable securities. Moreover, like all limited companies in Greece, PICs are required to retain at least $5 \%$ of their net earnings in order to form a regular reserve fund. This requirement is suspended when the respective reserve exceeds $100 \%$ of the PICs own share capital. On the other hand, PICs have to distribute to their shareholders a portion of their net earnings in the form of cash dividends. This is calculated as the maximum between the $6 \%$ of their share capital and $35 \%$ of their net 
earnings.

An important aspect for PICs is the tax environment. PICs are legally bound to pay tax at a rate estimated as $10 \%$ of the main refinancing operations rate (MRO) of the European Central Bank, augmented by a surcharge of $1 \%$. The tax is calculated on the semi-yearly average value of the PICs assets and is paid to the appropriate tax authorities within the first two weeks of July and January of the semester following the calculation. This tax payment essentially consists of the sole tax obligation of the PIC and its shareholders. In all other cases, PICs are exempted from taxes, duties, contributions, rights or any other charge in favor of the state. An exemption is the capital concentration tax (1\% on issued share capital) and the value added tax. Interest received by PICs is subjected to a deduction at the source, as provided by law (15\% on bank deposits and $10 \%$ on government securities). Dividends received are, in general, exempted from income tax.

\section{B. Institutional Aspects}

The first Greek CEF was founded in 1973. For almost a quarter of a century the number of CEFs in Greece has grown very slowly. By the end of year 1997, there were only fifteen CEFs listed in the ATHEX, which were primarily subsidiaries of large banking institutions (Hardouvelis, Angelidis and Tsiritakis, 2004). However, the rapid upturn of the market in 1998, and the hot market summer of 1999 offered an opportunity for small banking institutions and private investment lobbies to raise the required funds and to incorporate thirty-one new CEFs. Two of these funds applied for listings during the euphoric market times and managed to quote their shares on the ATHEX within a few months after incorporation. However, the remaining twenty-nine new funds did not receive their license to commence operations from GCMC until the marked had reversed to a rapid downward course which lasted until the end of year 2003.

During that period of market turmoil, the GCMC withheld all new listing procedures and postponed many approved new listings. As a result, the new CEFs were left operating as unlisted companies for a period of several months, varying from nine to fifty-eight months. For example, Active SA was one of the two lucky funds which, in September 1999 (immediately after incorporation), quoted its shares on the market. Notably, the next fund listing was more than two years later 
and concerns the one of Eurodynamiki SA in November 2001. Note that Eurodynamiki SA had begun operations in May 2000. Eventually, in the period from 2001 to 2005, thirteen out of the twenty-nine new CEFs managed to quote their shares on the ATHEX. The remaining sixteen funds failed to receive the GCMC's approval to go public and were either liquidated (in majority) or merged with other listed funds.

The new CEF listings increased the number of listed funds to a total of thirty funds, most of which had large institutional holdings. However, although in the years that followed the market displayed, on average, an upward trend, the majority of the CEFs gradually terminated operations and delisted their shares from the market. Specifically, by the end of year 2007 twenty-two out of the thirty listed funds had either been absorbed by their parent banking institutions or were merged with other funds of the same family (usually open-end mutual funds) and as a result the number of surviving CEFs fell to eight funds.

The reasons for the shrinking of the CEF industry in Greece has been an underrated research question. However, an important side-effect of the dramatic decrease in the number of active CEFs could be that the only form of collective investments available to investors is open-end mutual funds, which over the past years have steadily grown to an oligopolistic market controlled by a small number of over-sized financial institutions (i.e., Milonas, 1999; Babalos, Caporale, Kostakis and Philippas, 2008; Alexakis and Tsolas, 2011 among others).

\section{Methodological Issues}

\section{A. Closed-End Fund Data}

In the present study we use NAV and stock-price return data from two distinct but interactive CEF data sets. The first is a unique data set and consists of an unbalanced panel of the twenty-nine existing unlisted funds over a period of 68 months, from November 1999 to June 2005, covering a total of 835 firm-month observations. The second data set consists of an unbalanced panel of the thirty existing listed funds over a period of 132 months from January 1997 to December 2007, covering a total of 2,197 firm-month observations. Both data sets include surviving funds, new entrant funds as well as perishing funds, and therefore are free of any survivorship bias.

Fund return data are available through the website of the Association 
of Greek Institutional Investors (AGII). For the period under investigation, the AGII provides monthly NAV prices for all individual unlisted and listed funds and monthly stock prices for all individual listed funds. The AGII collects these data from the individual funds when they file mandatory periodic reports to the market supervising authorities (GCMC and ATHEX). Therefore, after adjusting for new issues of stock and stock splits, there is no reason to assume that there exists any sort of bias in these data.

\section{B. Return Metrics}

NAV prices are reported in the AGII database net of transaction costs, of fees paid to the Custodian Bank and of management fees. In Greece, these costs and fees are fully negotiable and it is practically impossible to trace them on a monthly basis for all individual funds. ${ }^{2}$ However, on average, transaction costs (including the securities transfer tax) that are paid as a commission to the brokerage houses (which are entitled to execute orders on behalf of the fund), range from 0.15 to $0.40 \%$ on the total amount of the transaction. The annual commission fees paid to the Custodian Bank range from 5 to 6 per mille on the average asset value of the fund. Finally, management fees include a fixed commission paid to the management company plus an extra fee if the funds' NAV return exceeds an agreed benchmark. Other management fees may include the fixed salaries paid to fund managers, which are not always tied to fund performance. For example, many Greek CEFs are subsidiaries of financial institutions. Thus management salaries may be linked to the pay scale of the parent company rather than to the performance of the fund.

In measuring the performance of a fund, it is important to decide whether to use net NAV returns or gross NAV returns. Clearly, gross returns are more appropriate when interest lies with assessing managerial performance (i.e., Cai, Chan and Yamada, 1997; Cesari and Paneta, 2002; Allen, Brailsford, Bird and Faff, 2003). However, because it has been impossible to collect information on management costs (especially for the unlisted funds) our main return metric has been net NAV returns. Nevertheless, in order to develop a perspective on gross NAV performance we follow Fama and French (2010) and estimate the yearly expense ratio for all funds for which information has been

2. Greek CEFs publish detailed information on their trading costs only since the introduction of the IFRS in 2005. 
TABLE 1. Summary Information of Greek Closed End Funds

\begin{tabular}{lcrrrr}
\hline Year & N & Total NAV $(€)$ & $\begin{array}{c}\text { Expense } \\
\text { Ratio }\end{array}$ & $\begin{array}{r}\text { Net NAV } \\
\text { Return }\end{array}$ & $\begin{array}{c}\text { Gross NAV } \\
\text { Return }\end{array}$ \\
\hline 1997 & 16 & $489,056,328.80$ & $1.28 \%$ & $50.1 \%$ & $51.4 \%$ \\
1998 & 16 & $984,490,198.07$ & $1.42 \%$ & $83.1 \%$ & $84.5 \%$ \\
1999 & 17 & $4,216,581,466.46$ & $1.46 \%$ & $210.8 \%$ & $212.3 \%$ \\
2000 & 17 & $2,802,752,084.14$ & $1.23 \%$ & $-37.5 \%$ & $-36.3 \%$ \\
2001 & 20 & $2,279,234,687.40$ & $1.58 \%$ & $-20.0 \%$ & $-18.5 \%$ \\
2002 & 24 & $1,711,592,904.24$ & $2.25 \%$ & $-26.4 \%$ & $-24.1 \%$ \\
2003 & 22 & $1,413,348,713.97$ & $2.24 \%$ & $13.9 \%$ & $16.2 \%$ \\
2004 & 20 & $1,336,220,595.34$ & $2.61 \%$ & $-1.6 \%$ & $1.0 \%$ \\
2005 & 11 & $354,678,929.64$ & $4.14 \%$ & $13.9 \%$ & $18.0 \%$ \\
2006 & 8 & $383,158,342.42$ & $3.80 \%$ & $20.8 \%$ & $24.6 \%$ \\
2007 & 8 & $412,606,682.26$ & $2.21 \%$ & $4.5 \%$ & $6.7 \%$ \\
\hline
\end{tabular}

Note: $\mathrm{N}$ is the number of operating funds at the end of each year. Total NAV is the sum of the net asset value of all active funds at the end of each year. The expense ratio is the sum of the management fees of all funds at the end of each year divided by Total NAV. Net NAV return is the annual compound value of the average monthly NAV return of all funds. Gross NAV return is net NAV return plus the expense ratio.

available. We then calculate monthly gross NAV returns by adding $1 / 12^{\text {th }}$ of the expense ratio on the net NAV return of each fund. Whenever the expense ratio for a fund is missing, we take the average expense ratio of all funds for this month. Yearly compounded net and gross NAV returns for all listed Greek CEFs are reported in table 1.

For the included regression models (examined in the next section), we construct the following variables. Our dependent variable is excess NAV (stock-price) returns $\left(R_{p, t}\right)$ calculated by deducting the risk-free rate of return $\left(R_{f, t}\right)$ from the funds' raw NAV (stock-price) return $\left(R_{N, t}\right)$. The monthly risk-free rate of return is approximated by the monthly yield of the 3-month Treasury Bills of the Greek Government. The independent variables in all our models consist of the excess return on the market portfolio $\left(R_{m, t}\right)$ which, whenever appropriate, is broken down into upside and downside market returns in order to capture the asymmetric response of fund managers to different market times. The monthly raw return on the market portfolio is approximated by the monthly return of the General Price Index (GPI) of the ATHEX. The excess market return is calculated by deducting the risk-free rate of return from raw market returns. Data for the 3-month T-Bill rates and for the GPI have been extracted from the monthly editions of the ATHEX. 


\section{Models of Portfolio Performance}

We use six models of portfolio performance evaluation, which are variants of the Sharpe - Lintner CAPM and of the Fama - French CAPM. These models are as follows:

\section{A. The Jensen (1968) Model}

The Jensen model consists of our first model to evaluate portfolio performance and is actually the standard CAPM, which advocates a linear relation between the excess portfolio returns and the excess market returns:

$$
R_{p, t}=\alpha+\beta R_{m, t}+\varepsilon_{p, t}
$$

where: $R_{p, t}$ is the excess portfolio return (either NAV or stock return in excess of the risk free rate) of fund $p$ in month $t ; \alpha$ is the intercept of the regression equation (alpha) which, measures the selectivity performance of the funds (i.e., Jensen, 1968; Fama, 1972); $R_{m, t}$ is the market premium (market return in excess of the risk-free rate) in month $t ; \beta$, is the slope of the regression equation (beta coefficient), which measures the average systematic risk of the funds; and $\varepsilon_{p, t}$ is a typical regression error term.

\section{B. The Henriksson and Merton (1981) Model}

This model is also known as the dual beta CAPM and relaxes the beta stability assumption of the CAPM by allowing for time-variations in the systematic risk of the portfolios. Merton (1981) and Henriksson and Merton (1981) opted to separate the constant systematic risk component from the changing time-dependent systematic risk component in the following manner:

$$
\begin{gathered}
R_{p, t}=\alpha+\beta_{t} R_{m, t}+\varepsilon_{p, t} \\
\beta_{t}=\beta+\gamma D_{t}^{+}
\end{gathered}
$$

where; $D_{t}^{+}$is a dummy variable that takes the value of 1 when the market premium is positive $\left(R_{m, t}>0\right)$ and zero otherwise; substituting 
equation 3 into equation 2 leads to the definition of a CAPM, with two target systematic risk factors known as the dual beta CAPM:

$$
R_{p, t}=\alpha+\beta R_{m, t}+\gamma R_{m, t}^{+}+\varepsilon_{p, t}
$$

where $R_{m, t}^{+}=D_{t}^{+} R_{m, t}$ equals $R_{m, t}$ when $R_{m, t}>0$ and zero otherwise.

The model in equation 4 consists of our second model of portfolio performance evaluation. It assumes that fund managers who exhibit good timing skills are able to increase the systematic risk of the portfolio during market up-times and reduce it when the market falters. Hence, the time dependent systematic risk coefficient is expressed as a function of excess market risk. A positive $\gamma$ slope shows a direct relation between portfolio systematic risk and excess market returns, displaying the managers' timing ability. The magnitude of the $\gamma$ slope in equation (4) measures the difference between the two target systematic risk factors, and is positive for a manager who successfully times the market.

In the special case when $\gamma=0$, equation (4) reduces to the Jensen model, where the $\beta$ slope is the sample estimate of the standard CAPM systematic risk.

\section{The Asymmetric Response Model (ARM)}

The Asymmetric Response Model (ARM) was first introduced by Fabozzi and Francis $(1977,1979)$ and Bawa, Brown and Klein (1981), and has been used by Pedersen and Satchell (2000) to test the portfolio performance of managed-funds. The ARM nests the one-factor mean-variance CAPM and the lower partial moment CAPM and can accommodate various degrees of non-normality in portfolio returns. The model captures asymmetry by producing positive and negative intercepts and excess return slopes for up and down market shifts, respectively.

The ARM, in its basic form, emerges by multiplying the intercept and the slope of equation 1 by the term $\left(D_{t}^{+}+D_{t}^{-}\right)$, where, $D_{t}^{+}$is a dummy variable that takes the value of one when $R_{m, t}>0$ and zero otherwise; $D_{t}^{-}$is a dummy variable that takes the value of one when $R_{m, t}<0$ and zero otherwise; and $D_{t}^{+}+D_{t}^{-}=1$. In this sense, the model captures differences in both selectivity and timing return components across market fluctuations in the following manner:

$$
R_{p, t}=\alpha_{1} D_{t}^{-}+\alpha_{2} D_{t}^{+}+\beta_{1} R_{m, t}^{-}+\beta_{2} R_{m, t}^{+}+\varepsilon_{p, t}
$$


where $R_{m, t}^{-}=D_{t}^{-} R_{m, t}$, and equals $R_{m, t}$ when $R_{m, t}<0$ and zero otherwise; and with all other variables being as previously defined. Equation 5 represents the Fabozzi and Francis (1979) version of the ARM, which captures the asymmetry in excess market returns through the slopes $\beta_{1}$ and $\beta_{2}$. The intuition of the model is that investors expect to receive a risk premium for downside risk (which is viewed as unfavorable) and pay a premium for upside variation of returns (which is viewed as favorable). The intercept $\alpha_{1}$ reflects the selectivity performance in downside markets, whilst the slope $\alpha_{2}$ reflects selectivity performance in upside markets. Positive values of $\alpha_{1}$ and $\alpha_{2}$ imply superior managerial selectivity abilities, whilst positive values of $\beta_{1}$ and $\beta_{2}$ indicate the timing skills of funds' managers. Moreover, by splitting market returns into upside and downside contributions, the ARM reflects whether the fund manager responds better in upside markets (if $\beta_{1}>\beta_{2}$ ) or in downside markets (if $\beta_{1}<\beta_{2}$ ).

An alternative version of the ARM prevails by adding and subtracting the term $\alpha_{1} D_{1}^{+}$in equation 5 , which yields the following rearrangement:

$$
R_{p, t}=\alpha_{1}\left(D_{t}^{+}+D_{t}^{-}\right)+\beta_{1} R_{m, t}^{-}+\beta_{2} R_{m, t}^{+}+\left(\alpha_{2}-\alpha_{1}\right) D_{t}^{+}+\varepsilon_{p, t}
$$

Knowing that $D_{t}^{+}+D_{t}^{-}=1$ and letting $\alpha_{1}=\alpha$, and $\alpha_{2}-\alpha_{1}=\delta$, and substituting in equation 6 yields the Bawa, Brown and Klein (1981) version of the ARM:

$$
R_{p, t}=\alpha+\beta_{1} R_{m, t}^{-}+\beta_{2} R_{m, t}^{+}+\delta D_{t}^{+}+\varepsilon_{p, t}
$$

The slope $\delta$ in equation 9 is a measure of incremental selectivity and reflects whether the fund manager responds better in upside markets (if $\alpha_{2}>\alpha_{1}$, then is positive) or in downside markets (if $\alpha_{2}<\alpha_{1}$, then $\delta$ is negative). If a fund manager performs equally well in both uptimes and downtimes, the slope $\delta$ should not deviate significantly from zero.

Another intuitive version of the ARM is obtained by adding and subtracting the term $\beta_{1} R_{m, t}^{+}$in equation 7 as follows:

$$
R_{p, t}=\alpha+\beta_{1}\left(R_{m, t}^{+}+R_{m, t}^{-}\right)+\left(\beta_{2}-\beta_{1}\right) R_{m, t}^{+}+\delta D_{t}^{+}+\varepsilon_{p, t}
$$

Knowing that $R_{m, t}^{+}+R_{m, t}^{-}=R_{m, t}$ and letting $\beta_{1}=\beta$, and $\beta_{2}-\beta_{1}=\gamma$, 
equation 8 transforms to an expression of the ARM that represents the Gujarati (1970) dummy-variables-technique for testing alpha and beta shifts around changing market regimes (i.e., in up and down markets):

$$
R_{p, t}=\alpha+\beta R_{m, t}+\gamma R_{m, t}^{+}+\delta D_{t}^{+}+\varepsilon_{p, t}
$$

The intercept $\alpha$ is a measure of selectivity performance and shows if a fund's manager possesses superior skills in picking successful shares. The slope $\beta$ represents a measure of the funds systematic risk. The slope $\gamma$ is a direct measure of managerial timing skills. An active manager who possesses superior timing skills must be able to foresee market uptimes (and downtimes) and increase (or reduce) the systematic risk of a fund's portfolio. In this case, the slope $\gamma$ must be positive and significant.

Equation 9 consists of our third model of fund performance evaluation and has the intuitive appeal that it nests the Henriksson and Merton model as well as the Jensen model. For example, when, $\delta=0$, equation 9 collapses to the Henriksson and Merton dual beta CAPM, while in the special case when $\delta=\gamma=0$, equation 9 becomes the standard econometric expression of the CAPM represented by the Jensen model.

\section{The Fama - French Model Adjustment}

We also obtain another three benchmark models by augmenting the above regression equation models with the Fama and French (1993) mimicking risk factors, which relate to size and to book-to-market ratios. In so doing, the Jensen model, the Henriksson and Merton model and the ARM transform to their respective three-factor versions as follows:

$$
\begin{gathered}
R_{p, t}=\alpha+\beta R_{m, t}+s S M B_{t}+h H M L_{t}+\varepsilon_{p, t} \\
R_{p, t}=\alpha+\beta R_{m, t}+\gamma R_{m, t}^{+}+s S M B_{t}+h H M L_{t}+\varepsilon_{p, t} \\
R_{p, t}=\alpha+\beta R_{m, t}+\gamma R_{m, t}^{+}+\delta D_{t}^{+}+s S M B_{t}+h H M L_{t}+\varepsilon_{p, t}
\end{gathered}
$$

In these regressions $S M B_{t}$ and $H M L_{t}$ are the size and book-to-market factor portfolio returns of Fama and French $(1992,1993)$. These factors 
are taken from Kousenidis, Maditinos and Sevic, (2011) who calculate them over the period from 1997 to 2007 and report some summary descriptive statistics for them. Thomakos and Koubouros (2011) also calculate $S M B_{t}$ and $H M L_{t}$ for the Greek Capital market in a similar manner albeit over a different time horizon.

Fama and French (2010) recognize that the inclusion of the average returns on the $S M B$ and $H M L$ portfolios in performance evaluation models is still controversial, since there is no clear-cut evidence on whether these two factors are rewards for risk or the result of mispricing. However, what they believe is that there is no need to take a stance on this issue as long as $S M B$ and $H M L$ are interpreted as diversified passive benchmark returns which capture potential patterns in the time series of individual fund returns associated with style investing. Therefore, when the portion of return variability, which is associated with $R_{m}, S M B$ and $H M L$, is removed from fund returns, researchers are better able to test for selectivity performance in the intercepts of the regression models.

\section{Empirical Results}

In the present section, we try to provide answers to two empirical questions. The first question concerns whether the funds, which successfully quoted their shares on the market, outperformed the funds that perished prior to going public. Moreover, we test whether there are any differences in the performance of the successful funds in the periods prior to and after their floating in the market.

The second research question concerns whether performance relates to fund survival. In particular, this question refers to whether the surviving listed funds have, on average, outperformed the funds that have perished. We study this empirical query in terms of NAV and market performance and we aim to shed light on the reasons why the CEF industry in Greece has shrunk so severely over the past years.

\section{A. The Performance of Unlisted Funds}

Table 2 summarizes the results of estimating the six regression models of fund performance for an unbalanced panel sample of unlisted funds (accounting for fixed period effects). All values are expressed in monthly returns and we use net as well as gross NAV returns as our dependent variables. Using net returns, the estimated selectivity 


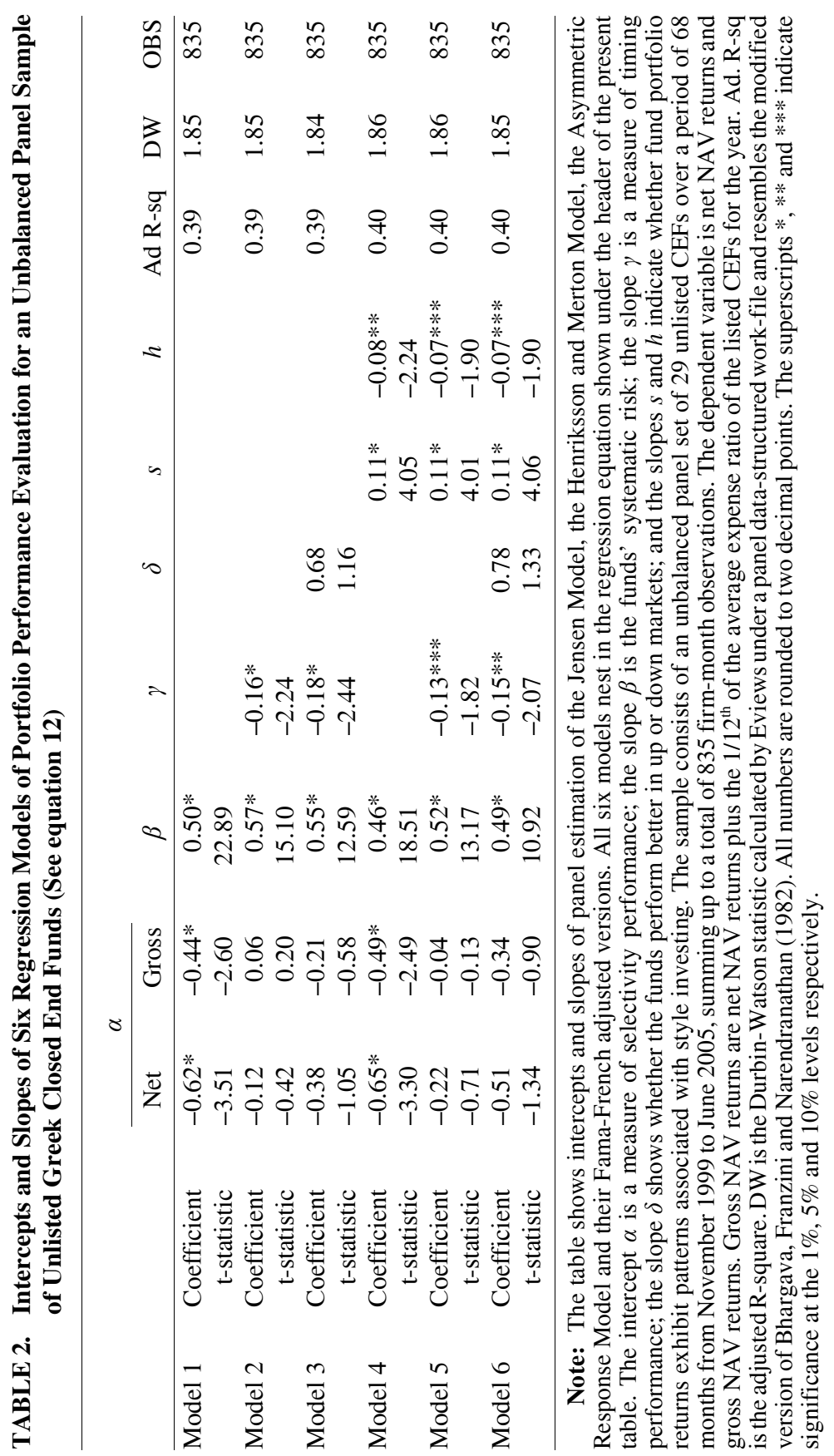


performance measure $\alpha$ is always negative, although significant only in two out of the six models: the single-factor Jensen model and its Fama-French three-factor version. Similar results are also obtained when we use gross returns as our dependent variable. The estimated $\alpha$ is slightly improved as compared to the net returns estimation, however it fails to produce evidence of selectivity skill sufficient to cover the average costs of portfolio management. In specific, it remains significantly negative in the cases of the single-factor and three-factor Jensen model; it becomes positive but insignificant in the case of the Henriksson and Merton model and continues to be negative but insignificant in the rest of the three models. Moreover, the fact that the $\delta$ slope is positive and insignificant for both the Asymmetric Response Model and its Fama-French adjusted version indicates that fund managers do not exhibit significant differences in selectivity performance across up and down markets.

When interest turns to risk estimation, the regression slope coefficients draw insightful inferences. First, the beta $(\beta)$ slopes are found significantly positive for all six regression models, however less than unity (ranging from 0.46 to 0.57 ). The observable implication is that the unlisted funds are tilted towards low systematic risk stocks. To further inquire on the risk preferences of fund managers, we look at the $s$ and $h$ slopes in models 4,5 and 6 . These indicate that the unlisted funds show some small but significant exposure to the size and book-to-market mimicking risk factors. While this result does not explain the observed underperformance, it offers some insight into the structure of fund portfolios. In particular, the $S M B_{t}$ slope is always positive and significant at the $1 \%$ level, indicating that the unlisted funds, which are young and small-size portfolios, are likely to hold smaller-size stocks relative to the market portfolio. On the other hand, the $H M L_{t}$ slope is negative and significant, at least at the $10 \%$ level. Although the value of the $h$ slope is small, its sign and magnitude reveal some preference of unlisted-fund managers towards low book-to-market (growth) stocks.

To assess the timing performance of the unlisted-fund managers we examine the $\gamma$ slopes in models 2, 3, 5 and 6 . The timing performance refers to the ability of the fund manager to foresee market movements and adjust the risk of his/her portfolio towards the right direction. In defining the regression models, we argue that a positive and significant $\gamma$ slope signifies the ability of a manager to successfully time the market. However, our results show negative timing coefficients, which are significant at least at the $10 \%$ level for all models of portfolio 


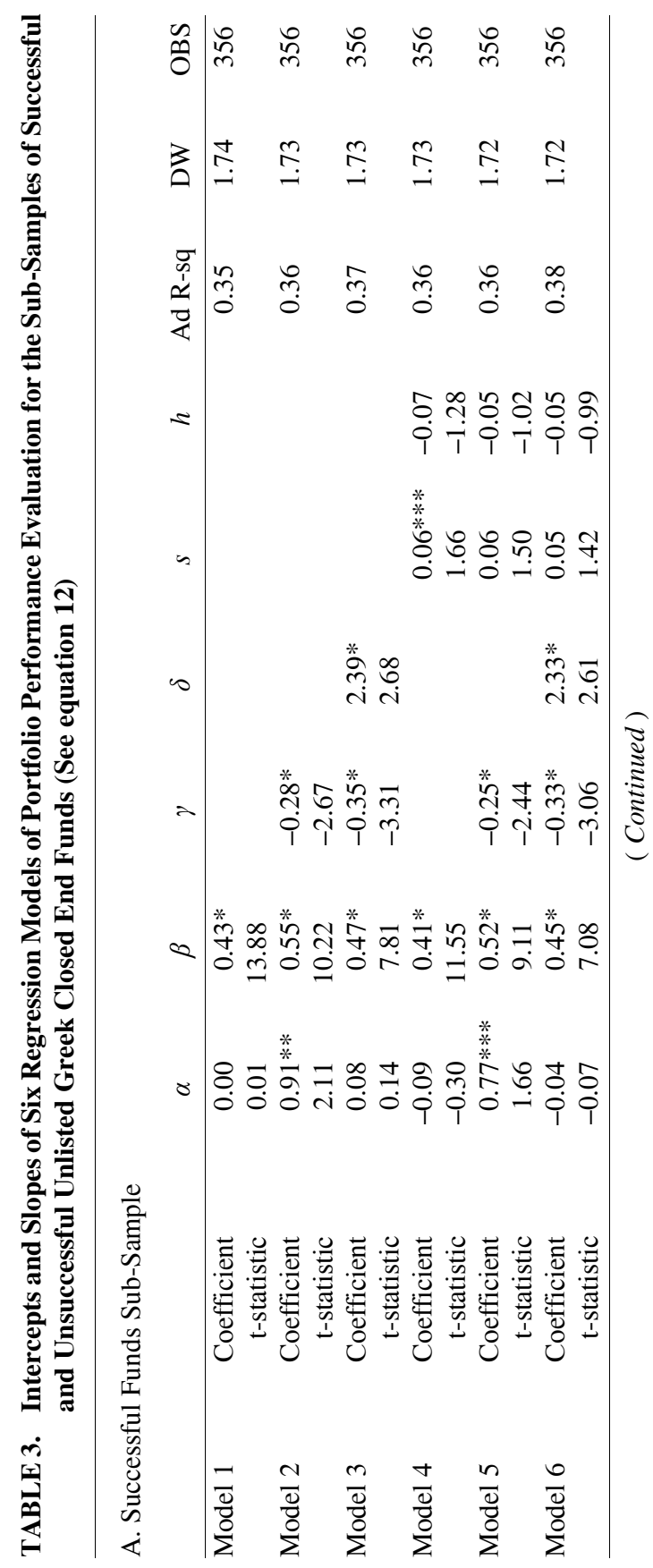




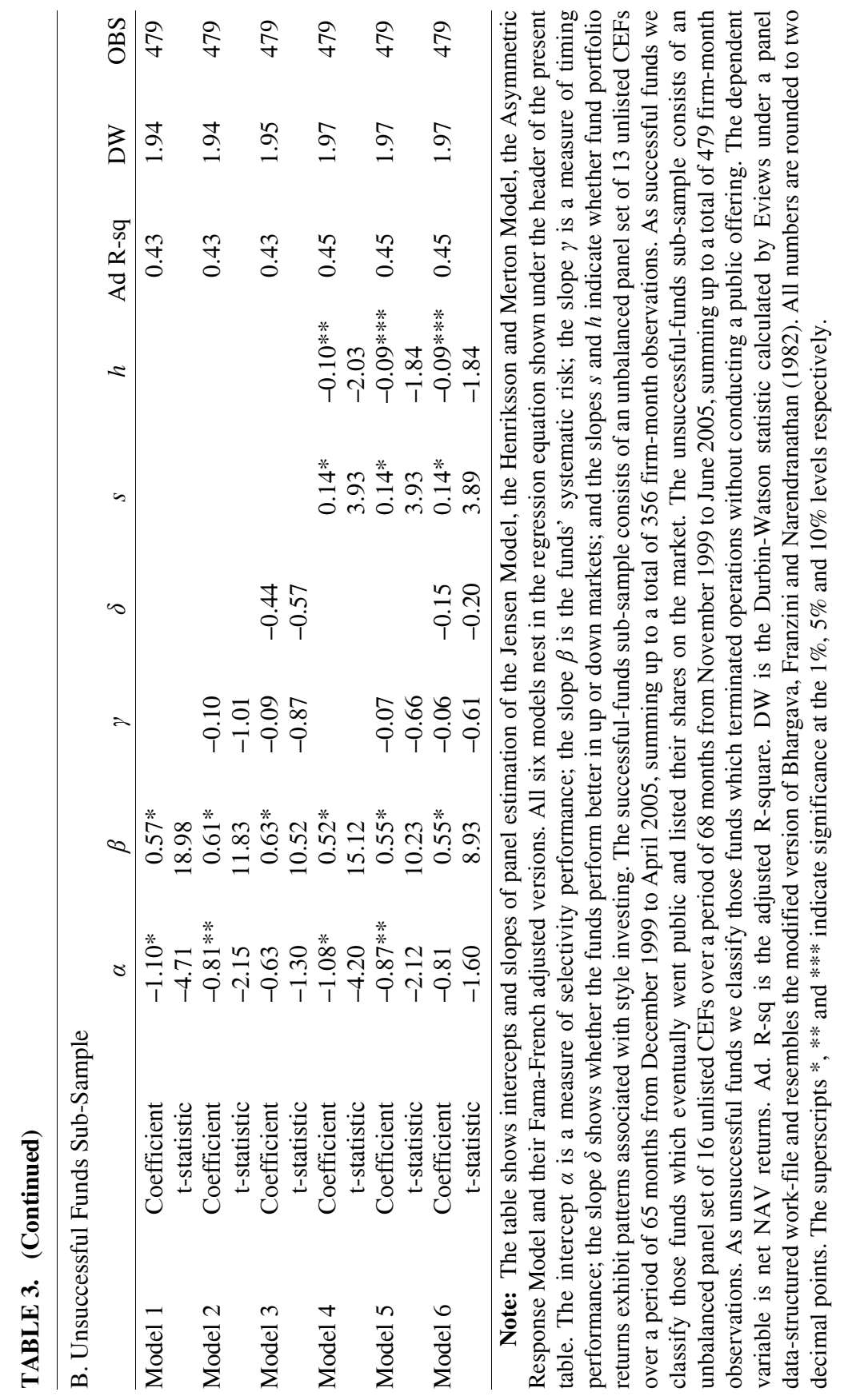


performance. The implication is that unlisted-fund managers engage in timing activities but display no superior skills in forecasting market movements. $^{3}$

In table 3 we split the full unlisted fund sample results into two sub-sample sets of results: panel A shows the successful-fund sub-sample results and panel B shows the unsuccessful-fund sub-sample results. Our goal is to draw inferences on differences in the average performance of the two sub-samples of funds. Hence, to reduce the possibility of bias resulting from using proxies of gross returns, we estimated the six models only on the net NAV returns of the funds falling within each sub-sample.

The first observable difference emerges by examining the selectivity performance of both successful and unsuccessful funds. Panel A shows that the intercept $\alpha$ is positive for four out of the six models and significant for two of them: the Henriksson and Merton model and its Fama-French adjusted version. On the other hand, panel B shows that the intercept is always negative and significant in four out of the six models. Moreover, the $\delta$ slope is positive and significant for the successful funds sub-sample and negative but insignificant for the unsuccessful funds sub-sample. Thus, in aggregate, the managers of successful funds display selectivity skills only in market uptimes. Conversely, the managers of unsuccessful funds consistently underperform in both up and down market times.

Moreover, the $\gamma$ slopes do not suggest much timing performance, especially for successful funds. The timing coefficient is always negative and significant for the successful funds sub-sample and negative but insignificant for the unsuccessful funds sub-sample. Interestingly, the coefficients of the $S M B_{t}$ and $H M L_{t}$ factors are found to be insignificant for the successful funds and significant for the unsuccessful funds.

Overall, we can infer that successful funds display some level of selectivity skills but exhibit negative timing performance. The latter however, is not driven by style investing. On the other hand, unsuccessful funds are tilted towards small-size and low book-to-market stocks. However, the variability of $\alpha$ across models does not allow us to conclude that underperformance relates to such an investment strategy.

3. Results not reported here indicate that a maximum number of 8 funds (among the 29 funds) deliver positive $\gamma$ slope in single-fund regressions; however, only 2 of them are found to be significant. Moreover, in running annual regressions, the results showed positive but insignificant $\gamma$ slope only in year 2001 and only for models 5 and 6. 


\section{The NAV Performance of Listed Closed-End Funds}

Table 4 tabulates the intercepts and slopes of our six regression models estimated for an unbalanced panel sample of listed funds (accounting for fixed period effects). The dependent variables in all panel estimations are net and gross NAV returns. Using net returns, the estimated selectivity performance measure $\alpha$ is positive for three out of the six models, albeit insignificant. For the other three models, $\alpha$ is negative, however it is only significant for one of them: the three-factor Jensen model. When we turn to gross returns, the estimated $\alpha$ is positive for four models and negative for two models, however it is always insignificant. Thus, our results fail to produce evidence of selectivity skill sufficient to cover the average costs of portfolio management. In addition, the $\delta$ slope is positive but insignificant for both the Asymmetric Response Model and its Fama-French adjusted version. The implication is that listed funds may perform good or bad without any systematic pattern. However, good and bad performance is split evenly in up and down markets.

Considering the risk estimates, we observe many similarities with the unlisted funds case. First, the $\beta$ slopes are found significantly positive and less than unity for all six regression models. The values of $\beta$ range from 0.63 to 0.67 , implying that, on average, Greek CEFs hold low risk portfolios. Moreover, the $\gamma$ slope is always insignificant and close to zero, indicating that funds do not shift to higher (lower) $\beta$ in ascending (descending) markets. On the other hand, the $s$ and $h$ slopes in models 4, 5 and 6 indicate that the listed funds show significant exposure to the size and book-to-market, mimicking risk factors. In specific, the $S M B_{t}$ slope is always positive and significant at the $1 \%$ level, indicating that the listed funds lean towards holding smaller-size stocks relative to the market portfolio. The $H M L_{t}$ slope is negative and significant at the $1 \%$ level, revealing the preference of listed-fund managers towards low book-to-market (growth) stocks.

In table 5 we analyze full-sample results to the results concerning the established-funds sub-sample (panel A) and the results concerning the young-funds sub-sample (panel B). To be consistent with the analysis of the unlisted funds, we employ net NAV returns as the dependent variable in the panel regression estimations. In terms of selectivity performance, our results show significant differences between established and young funds. The estimated $\alpha$ of the established funds is positive for five out of the six models, although significant only in one of them: the Henriksson and Merton model. The intercept $\alpha$ is 


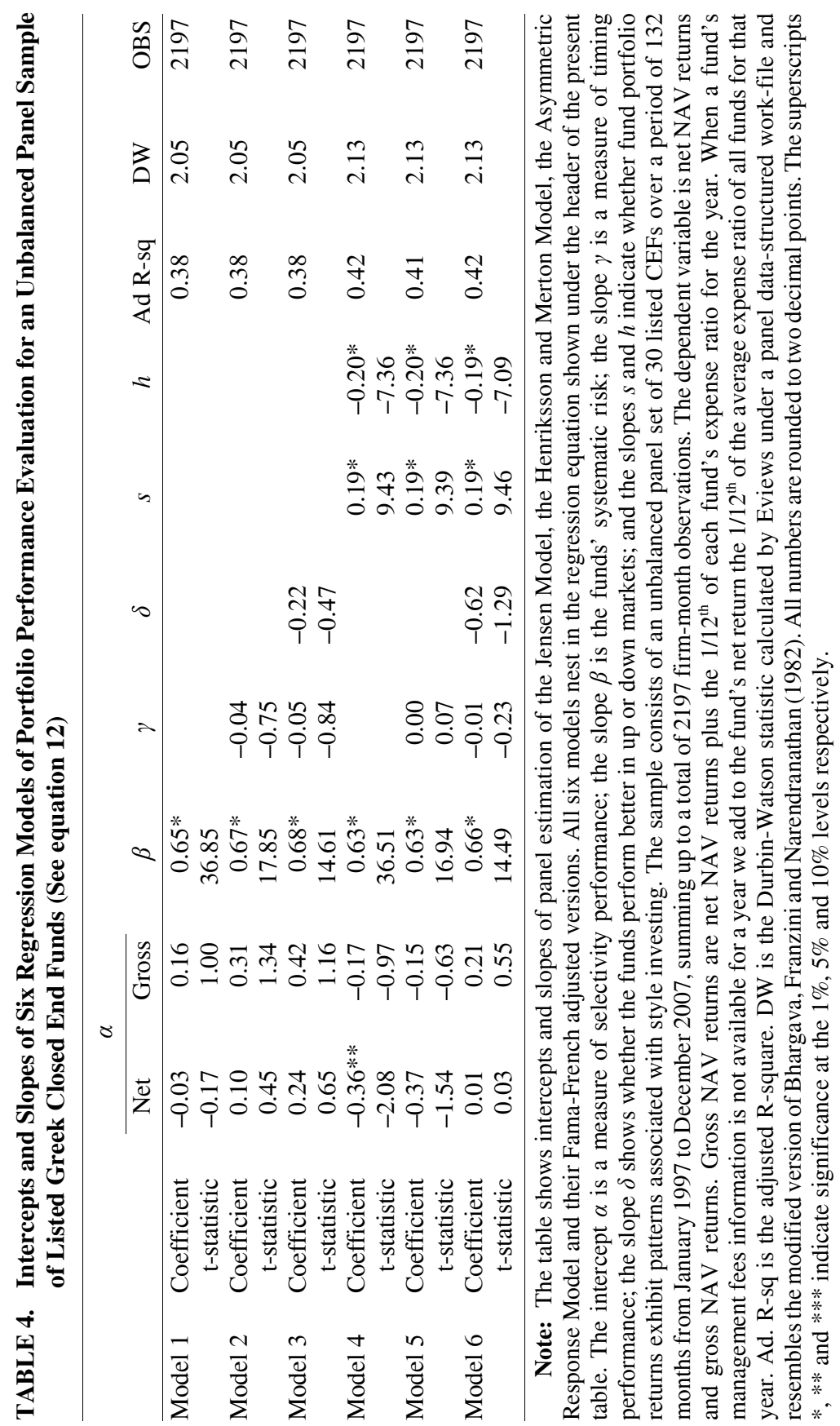


negative but very close to zero and insignificant only for the Fama-French version of the Jensen model. On the other hand, the estimated $\alpha$ for the young-funds sub-sample is always negative and significant at least at the 5\% level, thus qualifying the conclusion of young funds' underperformance.

Established and young funds share commonalities when it comes to the estimation of the risk-related slopes. Particularly, for both sub-samples, the $\beta$ coefficient is always positive and significant and takes values lesser than one. Consistent with the aggregate results, the $s$ slope is always positive and significant while the $h$ slope is always negative and significant, implying that both the established and the young funds maintain small-size and low book-to-market stocks in their portfolios.

In regard to timing performance, our evidence is mixed. First, the results of panel $\mathrm{B}$ show that the $\gamma$ coefficient is negative and insignificant for all four models, which account for timing performance (models 2, 3, 5 and 6). This clearly indicates that irrespective of the conditions that prevail in the market, young funds do not alter the risk of their portfolios. On the other hand, the results of panel A illustrate that the $\gamma$ coefficient is negative and significant for the two single-factor models, which include a timing component (models 2 and 3 ). Interestingly, the timing coefficient drops down in size and becomes insignificant when the $S M B_{t}$ and the $H M L_{t}$ factors enter the models. This finding raises the question as to whether part of the perverse timing relates to the fact that the established funds hold small-size and growth stocks in their portfolios. However, Antoniou, Galariotis and Spyrou (2005) tested for the profitability of contrarian investment strategies in the Greek capital market and showed (among others) that those investment strategies that buy small-size stocks outperform large-size strategies over the period from 1990-2000. Although they fail to produce similar evidence for book-to-market based strategies, their results seem to cast doubt on whether contrarian investment is the likely cause of fund underperformance. Nevertheless, the question as to why Greek funds are tilted towards small-size and growth stocks still remains. We believe that a reasonable answer to this question is liquidity, since small-size and low book-to-market stocks are likely to be more liquid stocks.

To strengthen our case on young fund underperformance, we estimated the six models of portfolio performance using single-fund data. In table 6 we summarize the number of positive (significant 


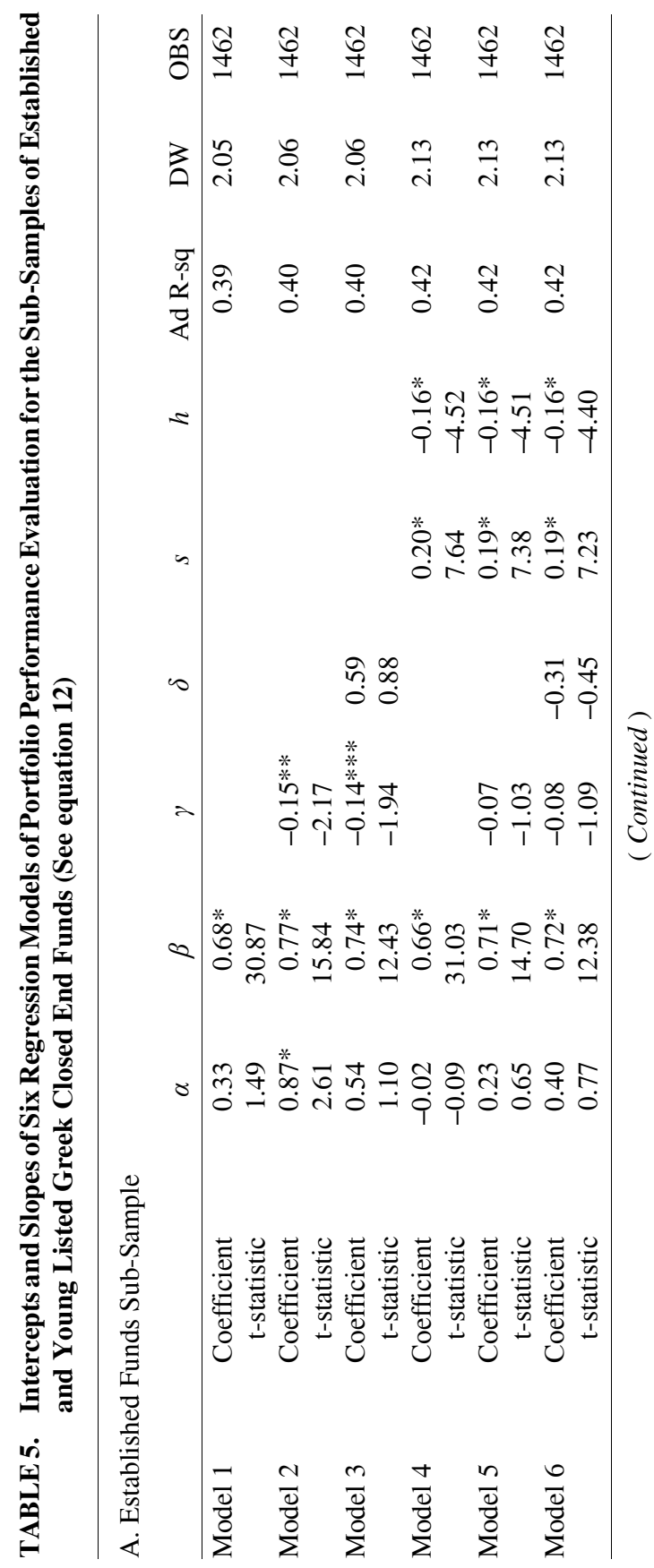




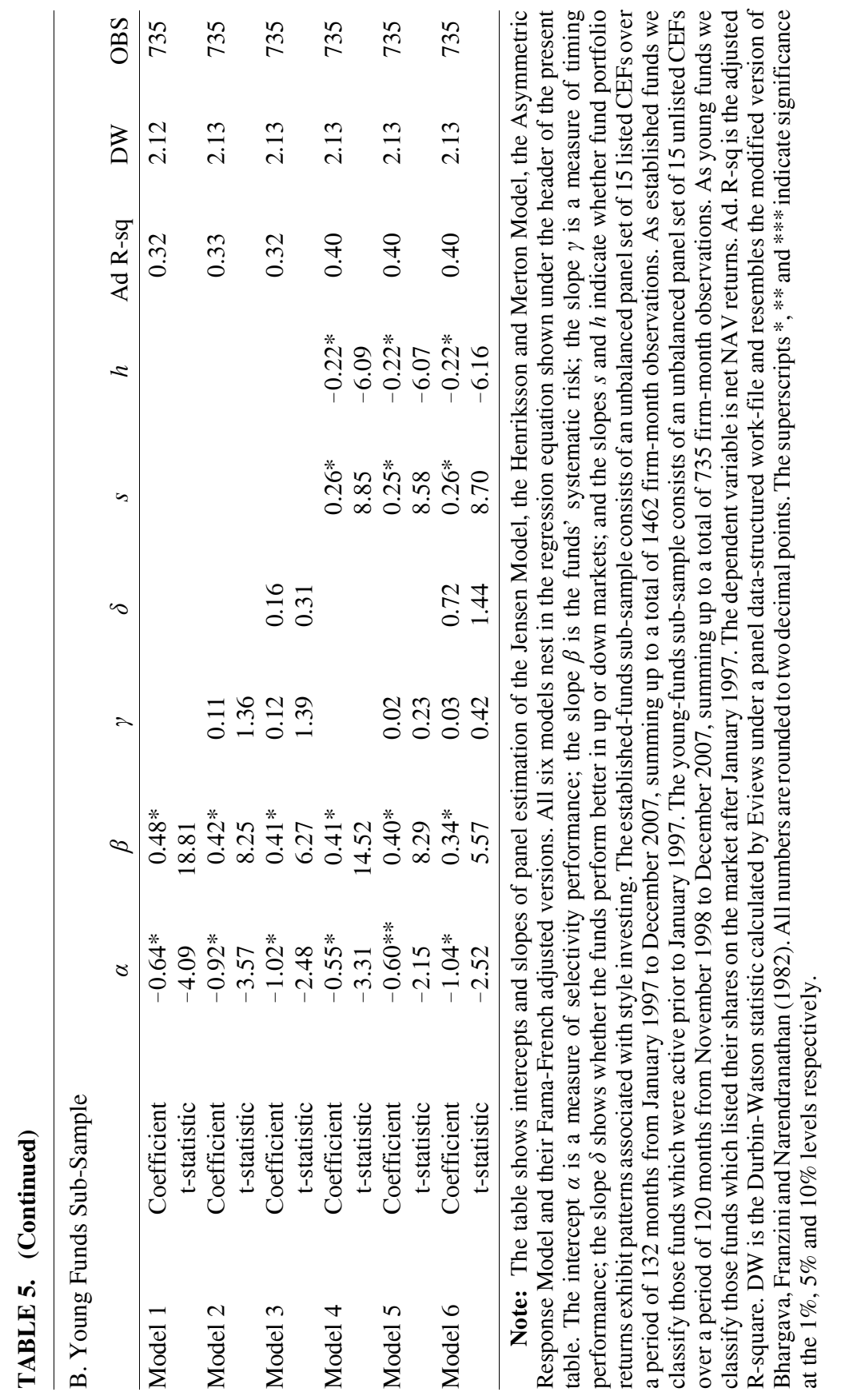




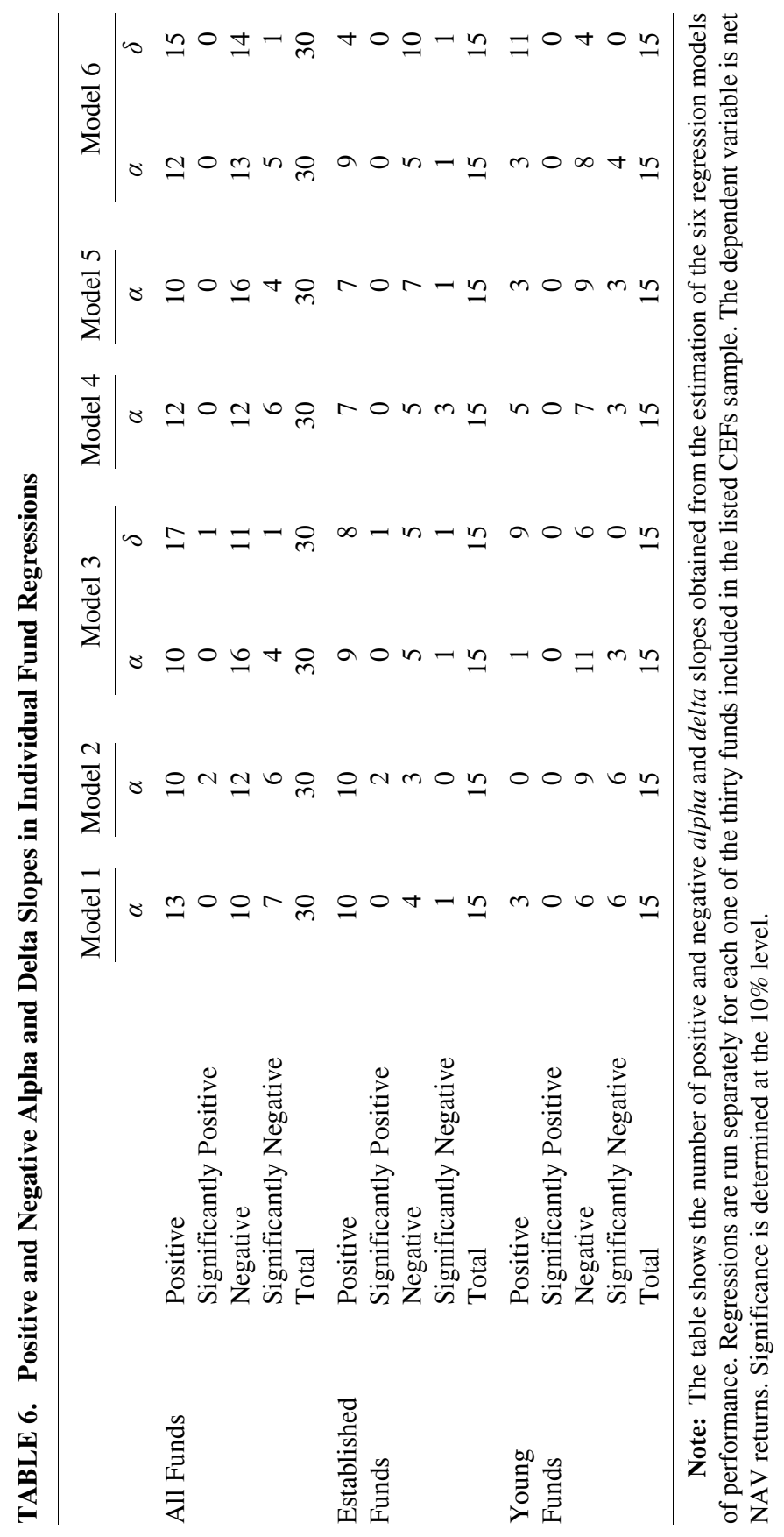


positive) and negative (significant negative) $\alpha$ and $\delta$ estimated coefficients. The results indicate that the vast majority of young funds have a negative and significant negative intercept $(\alpha)$, while none has a significant positive intercept. On the other hand, the majority of established funds have a positive intercept, albeit insignificant, in most of the cases.

Taken together the results of tables 5 and 6 qualify the conclusion of the underperformance of young funds. Like other studies, (i.e., Kaplan and Schoar, 2005) we document that established funds perform better than young funds, and in aggregate the underperformance of young funds dilutes the overall industry performance. However, we are unable to provide evidence that established funds deliver superior performance as compared to the market index.

A final issue concerns the question as to whether underperformance consists of a significant cause of loss of funds. To answer this question we run the six performance regression models for the two sub-samples of surviving funds (including all funds that remained active at least until December 2007) and of non-surviving funds (including all funds that terminated operations prior to December 2007). These results are tabulated in table 7. Panel A of table 7 illustrates the monthly NAV performance of the surviving funds sub-sample by model. On average, our results show that surviving funds deliver negative selectivity and timing performance (albeit insignificant) implying that superior NAV performance is unrelated to fund survival. Similar inferences are drawn when looking at the performance of non-surviving funds in panel B of table 7. Three models, the single-factor CAPM versions, show that the funds that discontinued operations deliver positive but insignificant alphas. On the other hand, the remaining three models (the three-factor CAPM versions) show that the terminated funds yield negative alphas, significant at the $10 \%$ level only in one out of the three models.

We also examined the performance of surviving and non-surviving funds by model and by fund, as well as by model and by year to test for performance differences across years in cases where fund terminations cluster in one or more years. These results are not reported here, however they are analogously inconclusive and make it difficult to relate NAV performance to fund survival.

\section{The Stock Market Performance of Greek Closed-End Funds}

The results reported thus far are based on the NAV performance of 


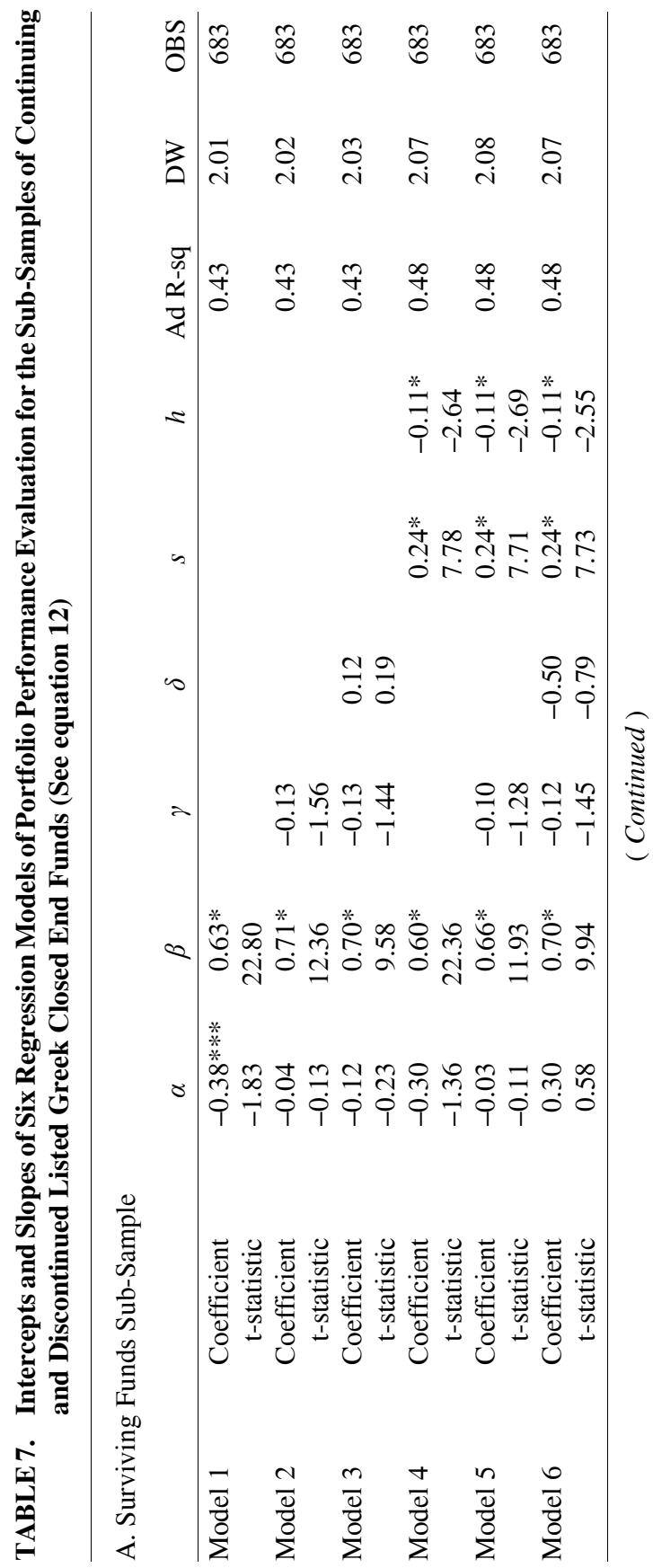




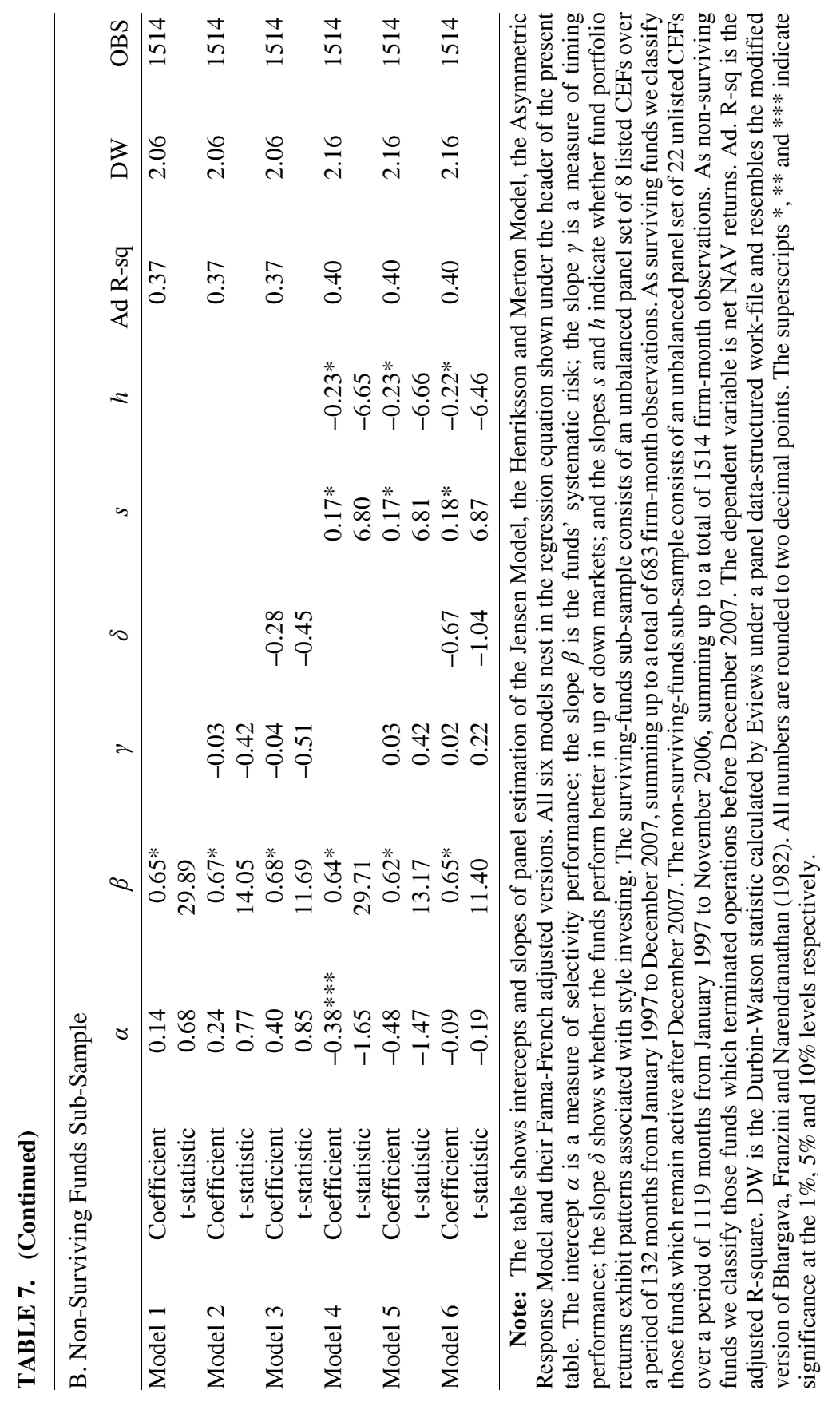




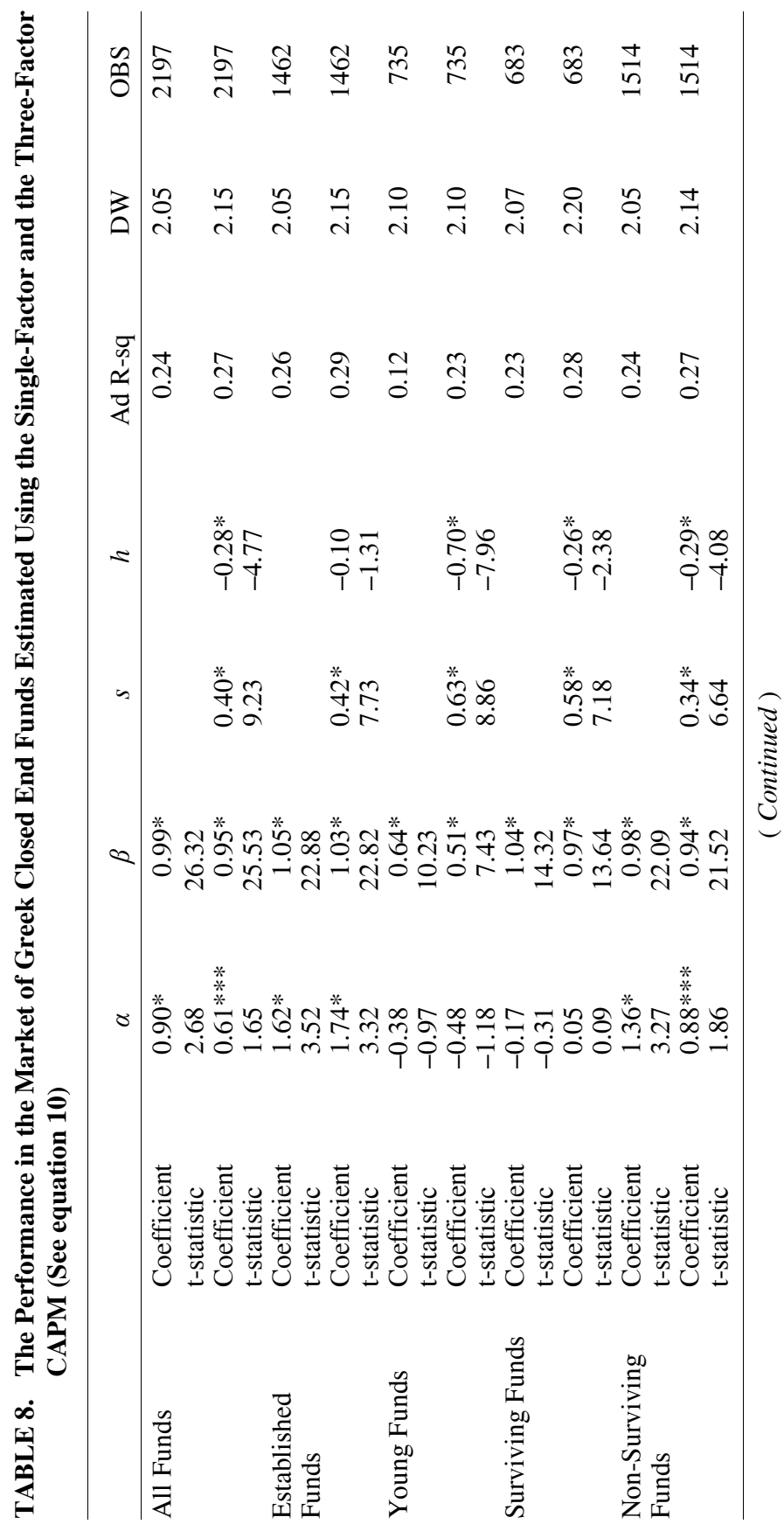




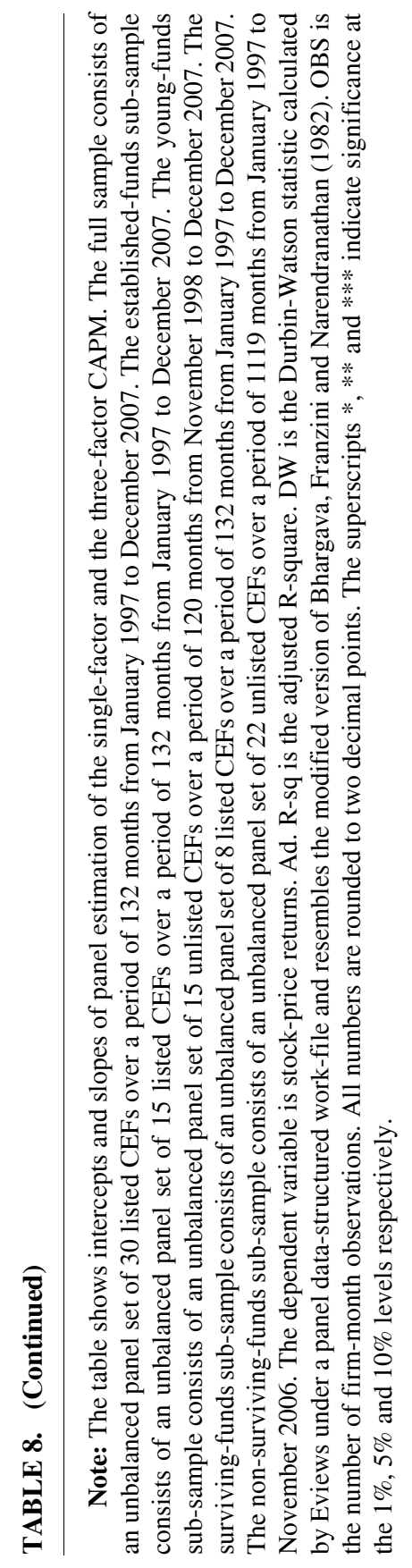


Greek closed-end funds and concern managerial selectivity and timing performance. We now take an investor's stand and examine how Greek CEFs perform in the market. Since we are not interested in testing for managerial selectivity and timing skills at this point in our research, we are only reporting on results stemming from two regression models: the single factor CAPM and the three-factor CAPM.

These results appear in table 8 and bear interesting implications. First, the full sample regressions result in positive and significant alpha intercepts and in beta slopes, which are close to one. It thus appears that the shares of the Greek funds are, on average, at the same level of systematic risk as the market. However, their aggregate performance is significantly better than the market, although in the case of the three-factor model significance is marginal (remaining at the $10 \%$ level). Moreover, in the three-factor CAPM, both the $S M B$ and the $H M L$ factors are significant, implying that these factors capture much of the variability in the returns of Greek CEFs.

Second, the performance results concerning the established and the young fund sub-samples clearly indicate that the established funds outperform the young funds. The alpha intercepts obtained with both the single-factor and the three-factor models are positive and significant (at the $1 \%$ level) for the established funds. The same intercepts are negative and insignificant for the young funds. Unlike the beta slopes of the established funds, the average beta slopes of the young funds are far smaller than unity, 0.64 for the single-factor model and 0.51 for the three-factor model, while the latter value is also smaller than the values of the $S M B$ and $H M L$ slopes ( 0.60 and -0.73 , respectively). Moreover, the value of the adjusted R-square obtained with the single-factor model is only $12 \%$, while the respective value obtained with the three-factor model is $23 \%$, implying that the variability in the returns of young funds is associated more with changes in the $S M B$ and $H M L$ factors rather than with changes in the returns of the market portfolio.

Considering the results for the surviving and non-surviving fund sub-samples, we note that non-surviving funds clearly outperform surviving funds, implying that superior performance inversely relates to fund survival. In particular, in the case of non-surviving funds, the alpha intercept with both regression models is positive and significant at least at the $10 \%$ level. On the other hand, in the case of surviving funds, the alpha intercept is negative and insignificant with the single-factor CAPM, while it is close to zero and insignificant with the three-factor 
CAPM.

To develop perspective on these results, we collected information on why funds (falling into the non-surviving-funds category) terminated their operations. This information is available on the AGII database, and reveals that, of the twenty-two perished funds, fourteen funds were absorbed by large financial institutions (usually the parental financial institution), three funds were absorbed by other funds of the same family, one fund was transformed into a mutual fund (open-end fund) and the final four funds were liquidated. Interestingly, the four funds that were liquidated were young funds with no or little institutional ownership. Moreover, the fact that Greek CEFs, over the period examined, were traded at large discounts (i.e., Kousenidis, Maditinos and Sevic, 2011) highlights that one of the likely motives of financial institutions to take over their subsidiary funds is to prevent these funds from hostile takeovers.

Overall, our results are in line with Kaplan and Schoar (2005) and Sentis (2009) and suggest that in hot market periods many underperforming funds conduct successful IPOs because of the presence of uninformed investors. ${ }^{4}$ The underperforming funds dilute the overall industry performance and, hence, well- performing funds are left with two options: either to stay in the market and keep on investing or to be taken over by a friendly bidder. In the latter case, the funds are delisted because of the acquisition and progressively only poor-performing funds remain in the market. This perspective suggests acquisition activity as a rational explanation for the phenomenon of the underperformance of surviving funds and also complies with Barras, Scaillet and Wermers (2010) who support that the observed fund-underperformance is owed to the long-term survival of a minority of truly underperforming funds.

\section{Summary and Implications}

The present paper examines the average performance of Greek closed-end funds over an eleven-year period from 1997 to 2007. Monthly data are used for an unbalanced panel of funds to estimate full-sample panel regressions and individual fund regressions. The

4. In the hot market summer of 1999 the number of active Greek investors was ten times what it was a few years later. 
regression models include the Jensen (1968) model, the Henriksson and Merton (1981) model, the Asymmetric Response Model (ARM) and their Fama and French (1993) three-factor versions.

Our primary results indicate that, on average, professional fund managers in Greece do not display superior timing and selectivity abilities and that their performance exhibits no significant differences across market fluctuations. Moreover, we find that the returns of funds are significantly exposed to the style factors of $S M B$ (positively) and $H M L$ (negatively) implying that Greek CEFs prefer to invest in small-size and low book-to-market stocks.

In addition, we address the issue of the underperformance of young closed-end funds in Greece. In this context, we find evidence that young funds, on average, underperform both old funds and the market. Moreover, we show that underperforming new funds are usually raised in hot market periods. The entrance of the newly raised funds in the market mitigates the overall industry performance and leads many well-performing funds to consider delisting their shares from the market instead of continuing investment in an underperforming industry. In our setting, the delisting mainly comes as the result of the acquisition of the fund by a friendly bidder, which is usually the parental financial institution. Thus, this acquisition activity prevails as a rational explanation for the underperformance and shrinking of the closed-end fund industry in Greece.

On the other hand, we are also able to offer a likely answer to the question why, unlike the closed-end fund industry, the open-end mutual fund industry has grown so rapidly over the past years (Babalos, Caporale, Kostakis and Philippas, 2008; Alexakis and Tsolas, 2011). It appears that, due to the large discounts at which Greek CEFs were traded at the time of our study, many financial institutions saw the opportunity to absorb their subsidiary CEFs to prevent them from being targets of hostile takeovers. Subsequently, financial institutions switched their portfolio investments to an open-end charter, specifically open-end mutual funds, which do not have shares traded on the market and hence are unlikely to be taken over by hostile bidders.

Overall, we argue that the underperformance of young funds is not another puzzling issue in the finance literature. Our findings indicate that underperforming new funds are raised during hot market periods. Like Sentis (2009), we support that the entrance and the long-term survival of the underperforming funds in the market are facilitated by 
the presence of a number of uninformed investors. These investors do not possess the discipline, time and technology to implement sophisticated diversification strategies by themselves (Baks, Metrick and Wachter, 2001) and hence are eager to buy shares of managed portfolios. Nevertheless, the question as to whether these investors would be better off if they switched to other forms of managed-portfolio investments is an issue that requires further investigation and goes beyond the scope of the present study.

Accepted by: Prof. P. Theodossiou, Editor-in-Chief, February 2013

\section{Appendix}

\section{A. An Overview of the Basic Performance of Individual Funds}

In this Appendix we report average monthly NAV and stock price returns, the standard deviation of these returns as well as the Sharpe Ratio for individual unlisted and listed Greek CEFs. The Sharpe ratio is the average monthly fund return minus the risk free rate divided by the standard deviation. The risk free rate of return is approximated by the monthly return of the 3-Month Treasury Bill of the Greek Government. Group A includes data for the unlisted funds sample. The first thirteen funds are the successful funds which managed to go public and henceforth are also included in Group B as listed funds. These funds along with the Marfin Classic and Active funds consist of the young funds sub-sample. All funds in Group B which have January 1997 as the beginning month of their return-data series consist of the established listed funds sub-sample. All funds in Group B which have December 2007 as the ending month of their return-data series consist of the surviving funds sub-sample. 


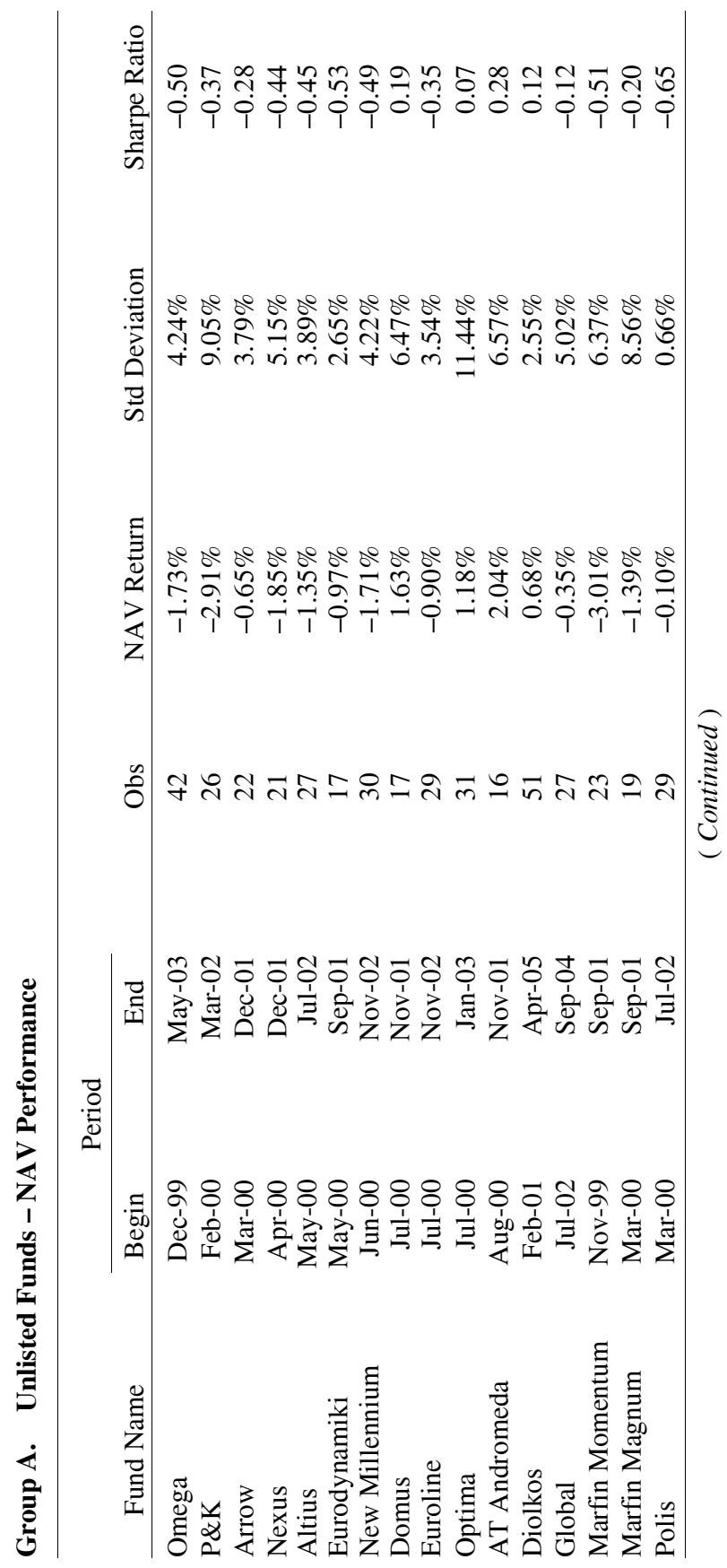




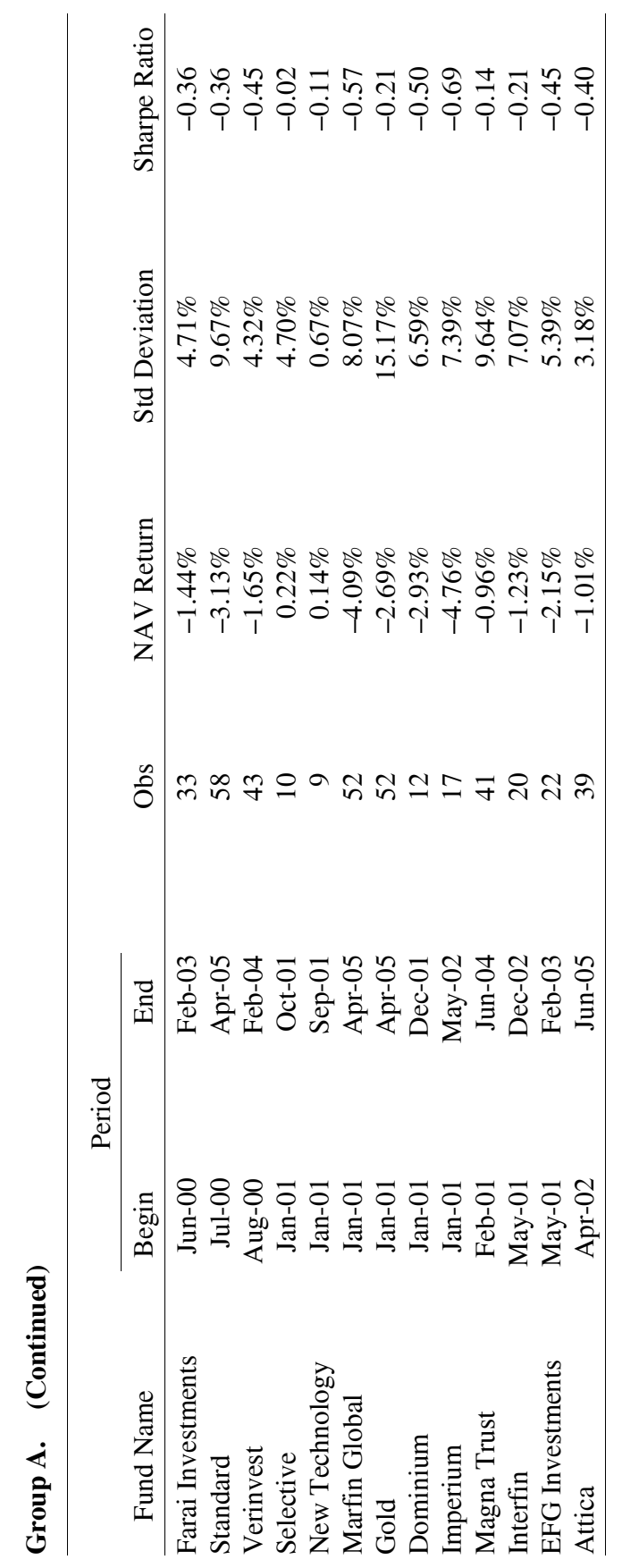




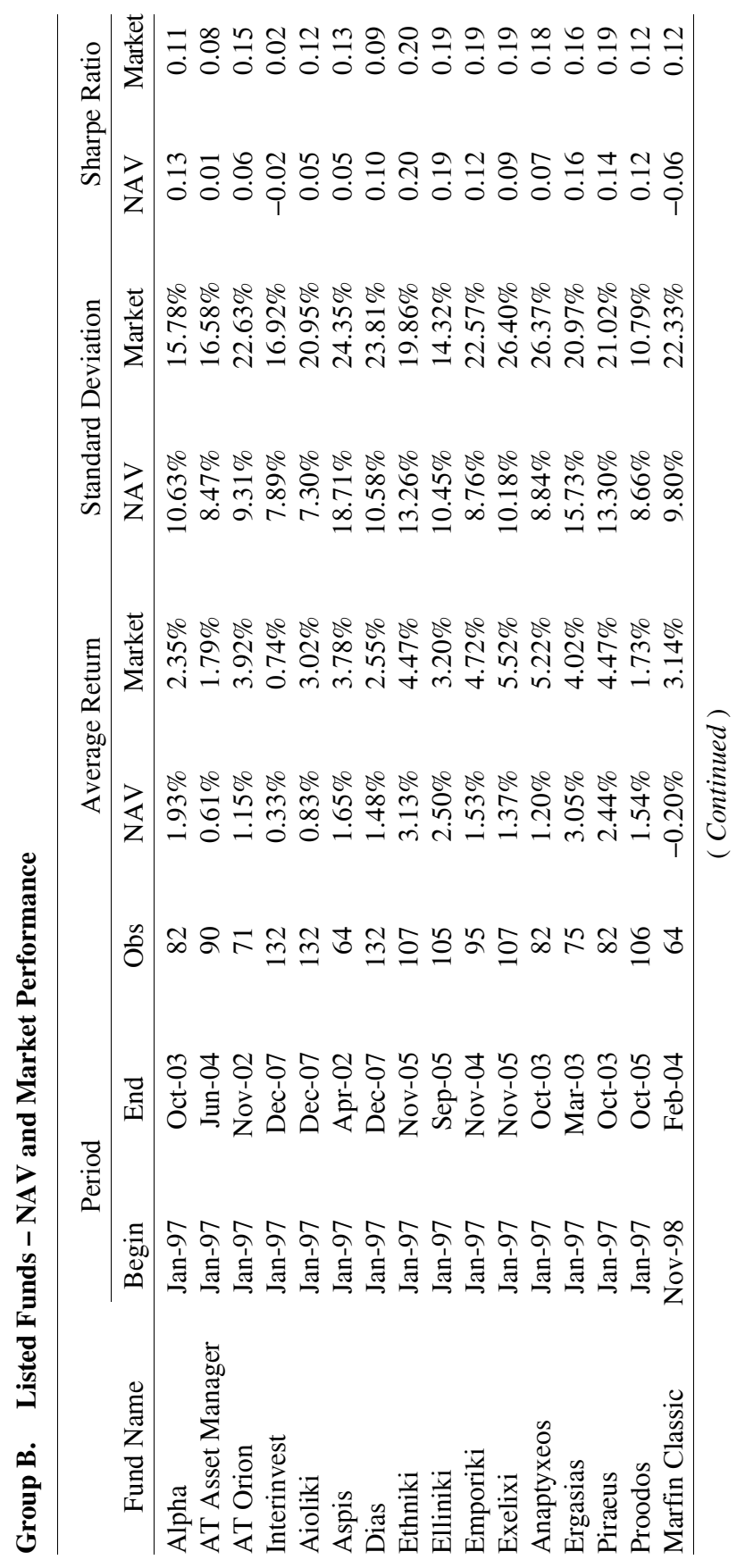




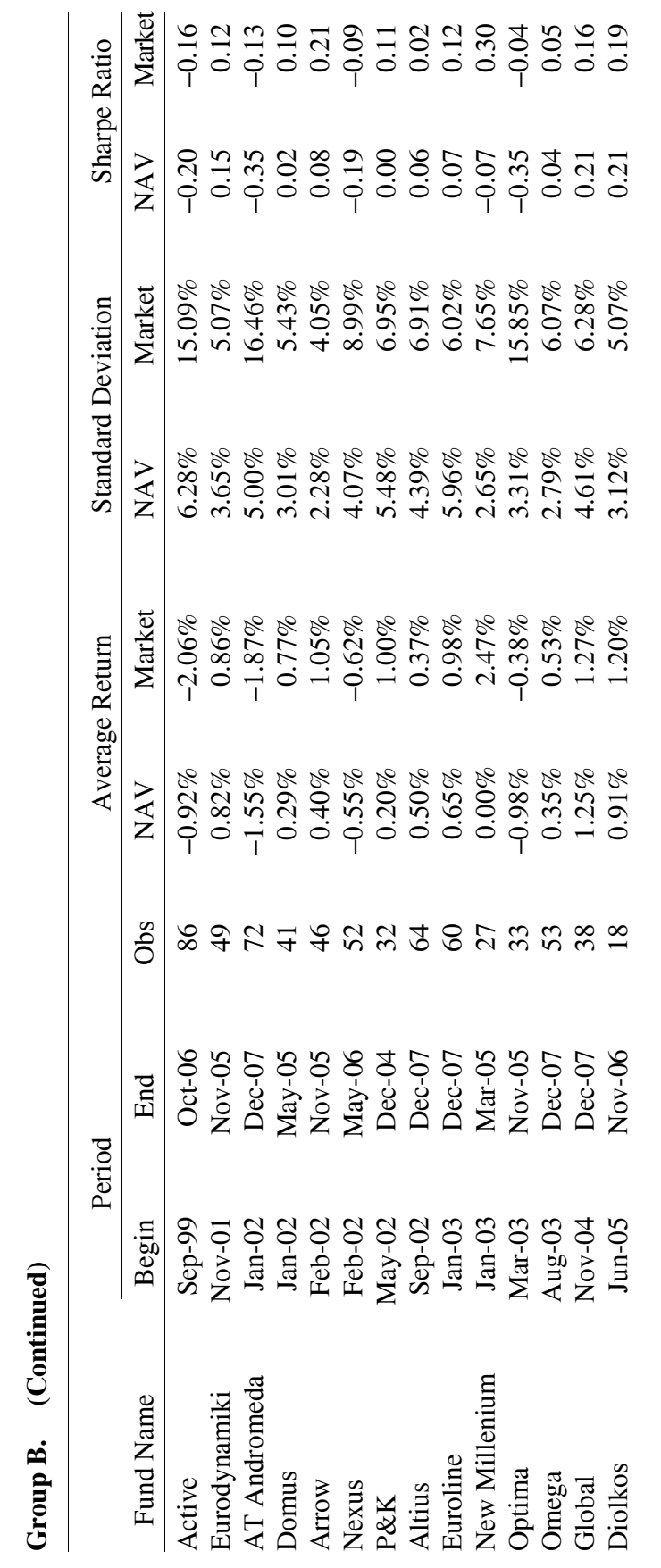




\section{References}

Alexakis, P., and Tsolas, I. 2011. Appraisal of Mutual Equity Fund Performance Using Data Envelopment Analysis, Multinational Finance Journal, 15: 273-296.

Allen, D.; Brailsford, T.; Bird, R.; and Faff, R. 2003. A Review of the Research on the Past Performance of Managed Funds, Report Prepared for the Australian Securities and Investment Commission by the Funds Management Research Centre (FMRC).

Antoniou, A.; Galariotis, E.C.; and Spyrou, S.I. 2005. Contrarian Profits and the Overreaction Hypothesis: The Case of the Athens Stock Exchange, European Financial Management, 11:71-98.

Babalos, V.; Caporale, G.M.; Kostakis, A.; and Philippas, N. 2008. Testing for Persistence in Mutual Fund Performance and the ex-post Verification Problem: Evidence from the Greek Market, European Journal of Finance, 14: 735-753.

Baks, K.P.; Metrick, A.; and Wachter, J. 2001. Should Investors Avoid All Actively Managed Mutual Funds? A Paper in Bayesian Performance Evaluation, Journal of Finance, 61: 45-85.

Barras, L.; Scaillet, O.; and Wermers, R. 2010. False Discoveries in Mutual Fund Performance: Measuring Luck in Estimated Alphas, Journal of Finance, 65: 179-216.

Bawa, V.; Brown S.; and Klein R. 1981. Asymmetric Response Asset Pricing Models: Testable Alternatives to Mean-Variance, Mimeo.

Berk, J.B., and Stanton, R. 2007. Managerial Ability, Compensation, and the Closed-End Fund Discount, Journal of Finance, 62: 529-556.

Bers, M.K., and Madura, J. 2002. The Performance Persistence of Foreign Closed-End Funds, Review of Financial Economics. 11:.263-285.

Bhargava, A.; Franzini, L.; and Narendranathan, W. 1982. Serial Correlation and the Fixed Effects Model, Review of Economic Studies, 49: 533-549.

Cai, J.; Chan, K.C.; and Yamada, T. 1997. The Performance of Japanese Mutual Funds, Review of Financial Studies, 10: 237-273.

Cesari, R., and Panetta, F. 2000. The Performance of Italian Equity Funds, Journal of Banking and Finance, 26: 99-126.

Cherkes, M.; Sagi J.; and Stanton R. 2009. A Liquidity-Based Theory of Closed-End Funds, Review of Financial Studies, 22: 257-297.

Dimson, E., and Minio-Kozerski C. 1999. Closed-End Funds: A Survey, Financial Markets, Institutions and Instruments, 8: 1-41.

Fabozzi, F.J., and. Francis, J.C. 1977. Stability Tests for Alphas and Betas Over Bull and Bear Market Conditions, Journal of Finance, 32: 1093-1099.

Fabozzi, F.J., and Francis, J.C. 1979. Mutual Fund Systematic Risk for Bull and Bear Markets: An Empirical Examination, Journal of Finance, 34: 1243-1250.

Fama, E.F. 1972. Components of Investment Performance, Journal of Finance, 
27: 551-567.

Fama, E.F., and French, K.R. 1992. The Cross-Section of Expected Stock Returns, Journal of Finance, 47: 427-465.

Fama, E.F., and French, K.R. 1993. Common Risk Factors in the Returns on Stocks and Bonds, Journal of Financial Economics, 33: 3-56.

Fama, E.F., and French, K.R. 2010. Luck versus Skill in the Cross-Section of Mutual Fund Returns, Journal of Finance, 65: 1915-1947.

Fuertes, A.M., and Thomas, D.C. 2006. Large Market Shocks and Abnormal Closed-End Fund Price Behavior, Journal of Banking and Finance, 30: 2517-2535.

Giles, T.; Wilsdon, T.; and Worboys, T. 2002. Performance Persistence in UK Equity Funds: A Literature Review, Association of Unit Trusts and Investment Funds, London.

Grossman, S., and Stiglitz J. 1980. On the Impossibility of Informationally Efficient Market, American Economic Review, 70: 393-408.

Gujarati, D. 1970. Use of Dummy Variables in Testing for Equality between Sets of Coefficients in Two Linear Regressions: A Note, The American Statistician, 24: 50-52

Hardouvelis, G.A.; Angelidis, T.T.; and Tsiritakis, E.D. 2004. Greek Closed-End Fund Premia: An Empirical Investigation, Working Paper, University of Piraeus - Greece (available on www.ssrn.com).

Henriksson, R., and Merton, R. 1981. On Market Timing and Investment Performance: Statistical Procedures for Evaluating Forecasting Skill, Journal of Business, 54: 513-533.

Jensen, M.C. 1968. The performance of Mutual Funds in the Period 1945-1964, Journal of Finance, 23: 389-416.

Kaplan, S.N., and Schoar, A. 2005. Private Equity Performance: Returns, Persistence and Capital Flows, Journal of Finance, 60: 1791-1823.

Kousenidis, D.V.; Maditinos, D.I.; and Sevic, Z. 2011. The Premium/Discount of Closed-End Funds as a Measure of Investor Sentiment: Evidence from Greece, Journal of Applied Business Research, 27: 29-51.

Lang, L.H.P.; Litzenberger, R.H.; and Madrigal, V. 1992. Testing Financial Market Equilibrium under Asymmetric Information, Journal of Political Economy, 100: 317-348.

Lewellen, J. 1999. The Time-Series Relations among Expected Return, Risk and Book-to-Market, Journal of Financial Economics, 54: 5-43.

Merton, C. 1981. On Market Timing and Investment Performance. I: An Equilibrium Theory of Value for Market Forecasts, Journal of Business, 54: 363-406.

Milonas, N. 1999. Greek Mutual Funds, Athens: Hellenic Bank Association and Sakoulas Editions, (in Greek).

Pedersen, C.S., and Satchell, S.E. 2000. Small Sample Analysis of Performance Measures in the Asymmetric Response Model, Journal of Financial and Quantitative Analysis, 35: 425-450. 
Ritter, J. 1991. The long-Run Performance of Initial Public Offerings, Journal of Finance, 46: 3-27.

Sentis, P. 2009. Merging Activity as a Rational Explanation for the Long-Run Underperformance of IPO, Multinational Finance Journal, 13: 75-102.

Thomakos, D.D., and Koubouros, M.S. 2011. The Role of Realized Volatility in the Athens Stock Exchange, Multinational Finance Journal, 15: 67-124. 